\title{
Schumpeter and Quantitative Research in Economics
}

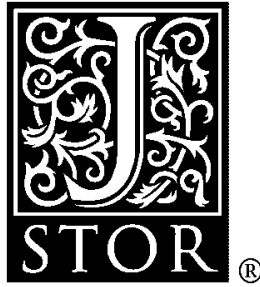

\section{J. Tinbergen}

The Review of Economics and Statistics, Vol. 33, No. 2. (May, 1951), pp. 109-111.

Stable URL:

http://links.jstor.org/sici?sici=0034-6535\%28195105\%2933\%3A2\%3C109\%3ASAQRIE\%3E2.0.CO\%3B2-A

The Review of Economics and Statistics is currently published by The MIT Press.

Your use of the JSTOR archive indicates your acceptance of JSTOR's Terms and Conditions of Use, available at

http://www.jstor.org/about/terms.html. JSTOR's Terms and Conditions of Use provides, in part, that unless you have obtained prior permission, you may not download an entire issue of a journal or multiple copies of articles, and you may use content in the JSTOR archive only for your personal, non-commercial use.

Please contact the publisher regarding any further use of this work. Publisher contact information may be obtained at http://www.jstor.org/journals/mitpress.html.

Each copy of any part of a JSTOR transmission must contain the same copyright notice that appears on the screen or printed page of such transmission.

JSTOR is an independent not-for-profit organization dedicated to and preserving a digital archive of scholarly journals. For more information regarding JSTOR, please contact support@jstor.org. 


\section{SCHUMPETER AND QUANTITATIVE RESEARCH IN ECONOMICS}

\section{J. Tinbergen}

$\mathrm{T}$ HE difficulty of giving a correct appraisal of so many-sided a talent as Schumpeter was is evident. The following impressions relate to only one aspect of the writings of this complicated and almost mysterious mind; they try to find out what his attitude was toward the type of economist we may call "model builders" in the econometric sense.

Schumpeter was among the enthusiastic founders of the Econometric Society. In fact, the very first contribution to Econometrica apart from the "Editorial" — was his "The Common Sense of Econometrics," 1 one of the masterpieces of vision, eloquence, and harmony, characteristic of his work. In the paper he expresses a warm sympathy for, and a strong belief in, econometric research. It is striking, therefore, that upon a careful study of his own largest publication since then Business Cycles $^{2}$ — one finds a mental attitude vis-à-vis econometric work which is not only rather critical, but to some extent alien to it. A critical attitude can never be a reason for concern: keen analysts will always have to make critical comments of anything that others have wrought, and only at the benefit of further progress. What strikes one to some extent is, however, that the mental approach to the problems which seems to be behind many parts of Business Cycles looks so different from the approach common to most econometricians. If this approach is correct, it seems to me to be worth while to consider it further, since it might contribute to the mutual understanding of econometricians (as I see them) and others, Schumpeter in his broad approach perhaps representing both.

The space devoted to typical econometric research in this one-thousand-page book is relatively small. The place given to the descrip-

\footnotetext{
${ }^{1}$ Econometrica, I (1933), p. 5 .

${ }^{2}$ Joseph A. Schumpeter, Business Cycles: A Theoretical, Historical and Statistical Analysis of the Capitalist Process (New York and London, I939, 2 vols.).
}

tion of facts, to a somewhat primitive chartreading, and to institutional consideration is very much larger. The treatment, even of theoretical points, is quite different from the econometric habit of a rigorous subdivision according to the relations discussed - e.g., a sharp distinction between the demand and the supply side, to quote the simplest case. ${ }^{3}$

But it is not only the outer form of his treatment which strikes the econometrist as noneconometric. The difference goes much deeper; it is, in fact, the impression of his whole attitude vis-à-vis the setting of the problems and their solution. I shall try to make my position clear from a number of cases in point.

First, as to the setting of the problem "how to explain the business cycle phenomenon?" I think the general econometric view now is to state that the phenomenon of the rather irregular movements we are accustomed to call business cycles must be understood as the coöperation of essentially two elements, both relevant to the explanation, viz., a mechanism capable of performing characteristic cyclical movements ("Eigenschwingungen" as the German physicists call them) and exogenous "shocks" as initial movers. Schumpeter shows a scarcelyhidden preference for the shocks to be the "true" "causes" and tends to belittle the importance of the mechanism. Discussing the hog cycle, he concludes: " "What we behold when looking at those hog graphs that are so remarkably regular is nothing but [my italics] the wavelike, to be sure - working of a particular apparatus of response."

Similarly, about the coffee market he says: ${ }^{5}$ "Only [my italics] the form of these fluctuations is shaped by the structural properties of the coffee resonator. ..."

\footnotetext{
${ }^{3} \mathrm{Cf}$., in particular, his treatment of separate markets in Chapter $\mathrm{x}$, for which subject this technique would seem the ideal one.

${ }^{4}$ Business Cycles, II, p. 533 .

${ }^{5}$ Ibid., p. 530 .
} 
When discussing his own theory, that of the innovations, the emphasis is also more on these "shocks" than on the mechanism.

The point is more important than a mere difference of emphasis would be. In the mind of the econometrists, the mechanism deserves the main attention especially, because what we can influence is much more the structure of the mechanism than the occurrence of the shocks. Business-cycle policy, in whatever form, always comes down to changing the structure of the "response mechanism" or the "resonator" the word is very well chosen by Schumpeter so as to increase its damping degree and hence to "nip in the bud" the cumulative processes provoked by the shocks.

By the way, it may be questioned whether the shocks of innovations are so much the leading ones. His monolithic theory is remarkable enough for one like Schumpeter, with his sense of the complexity of things. Are not agricultural shocks also very important and could they not even explain especially the Kitchin ${ }^{6}$ It is, in this respect, interesting to quote from Business $C y c l e s$ that, among prices, food and textile prices (and those of textile machinery) show the Kitchin more markedly than metal prices. The same is true for the demand for shipping (where grain transports play an important rôle) as distinguished from the cost of shipping (where coal prices are predominant).

Also his opinion on the nature the mechanisms under discussion shows remarkable deviation from the usual econometric approach. Discussing the possibility, put forward by the "self-generating theories," that the causation of prosperity lies (to some extent at least) in the conditions prevailing in depression, he adds: ${ }^{7}$ "This line of reasoning may perhaps serve ... in order to account for revival $u p$ to normal [my italics], but obviously cannot serve beyond that."

Anybody who is familiar with the theory of econometric models, to which the italicized passages do not apply, wonders what exactly Schumpeter may have had in mind here.

Throughout his treatment of the businesscycle mechanism, he is very much in favor of

\footnotetext{
${ }^{6}$ Cf. J. Tinbergen and J. J. Polak, The Dynamics of Business Cycles (Chicago, 1949), p. 2 I4.

${ }^{7}$ Business Cycles, I, p. I39, note.
}

a-cyclic, or at least heavily damped, mechanisms. This may, from a realistic point of view, be very wise. From a purely theoretical point of view it would not seem justified, however. His assertions that undamped mechanisms are like a perpetuum mobile, or his comment on Kalecki's model that the starting impulse might have been some trouble in the apple-growing industry at the time Adam and Eve dwelt in Paradise - however refreshing this latter idea be - seem to indicate such an unjustified theoretical belief against periodic endogenous movements.

Another passage in his discussion of econometric models, when dealing with reinvestment cycles, also strangely collides with econometric results. He seems to think that an explanation of the cycle based on the "echo principle" has as a necessary condition that the lifetime of all machines be the same. ${ }^{8} \mathrm{He}$ seems to be unaware of the fact that the very relation he emphasizes, viz., that between reinvestment and the general economic situation, is sufficient to explain even undamped reinvestment cycles with distributed lifetimes.

Throughout he considerably, in my opinion, understates the degree of generality of the validity of the theorems on cycles put forward by econometrists. When discussing - may I add, generously - the shipbuilding model I once put forward, he states, among other things: ${ }^{9}$ "Freight rates are not an invariant function of tonnage alone and, as soon as this is recognised, there is an end of this particular cycle."

If the function varies, or if other variables come in, there need not at all be "an end" to this cycle. If one of these other variables be the price of new ships - another objection made - the same answer applies, in particular when this variable, according to Schumpeter's graph XXII (p. 535), appears to be, with great approximation, a function of freight rates. Neither does the theory of the shipbuilding cycle rest on the necessary assumption that the reaction of carriers "to freight rates be mechanical." 10

A question perhaps more of terminology would seem the statement that the cycle just

\footnotetext{
${ }^{8}$ Ibid., p. I90.

${ }^{9}$ Business Cycles, II, p. 534 .

${ }^{10}$ Ibid.
} 
discussed is not an endogenous one, because it depends on some disturbance "that starts them." 11

The didactic value seen by a number of "model builders" in the clear distinction between the explanation of (i) the period, (ii) the shape, and (iii) the amplitude of some of the simple cycles, each of them having separate determinants, does not seem to have impressed Schumpeter either, when he concludes about the coffee cycle that "the form of these fluctuations is shaped by the structural properties of the coffee resonator, of which the lag is one." The lag is typically responsible for the period, but not for the form; the disturbing shocks are determinants to the form.

Finally, a difference of opinion on the economic contents of one particular relation in a certain model may be quoted. In that model it was assumed that the volume of production is - apart from a lag resulting from the production period - determined by the rate of increase of profits and the rate of increase of other incomes (as far as not saved) as the only determinants. The present author is of the opinion that this assumption is rather strange; in fact, in no other model so far presented has it ever been adhered to. Schumpeter, according to an anticritical note, ${ }^{12}$ evidently considered it rather reasonable.

Are these few remarks an expression of some "dépit" that Schumpeter was rather critical, in

${ }^{11}$ Ibid.

${ }^{12}$ Business Cycles, I, p. 185, note $\mathrm{I}$.
I 939, vis-à-vis some of the econometric models of cycles that had been put forward since his warm recommendation of the econometric method in I933? If so, the only reaction of the reader should be: Evidently many model builders have to learn something from Schumpeter's universal knowledge and insight, the more so since one cannot expect him to have been biased against their work! At any rate, this is an important conclusion that the present writer wants to draw. But there is another, a somewhat puzzling one: Evidently Schumpeter "lived another life" than most econometrists. What exactly did econometrics mean to him? Did he feel at home with it, or did he not? What is the sense of the divergencies just stated? In the opinion of the writer it cannot be explained only by the grief Schumpeter expresses ${ }^{13}$ concerning "the difficulties which exact methods of analysis are sure to meet."

As I have said, these remarks may be of some slight use in clearing a few misunderstandings about econometric models. It is only too bad that Schumpeter himself cannot answer them. They by no means do justice to the book on which they bear, and they are not meant to do so. In fact, even the chapters to which they refer are so crowded with important remarks on the theory of cycles as well as on actual economic life that, taken as a whole, they can only confirm the impression of Schumpeter's thorough knowledge and experience.

\footnotetext{
${ }^{13}$ Business Cycles, II, p. 530. Cf. also Professor Samuelson's and Professor Smithies' essays in this issue. - Ed.
} 
http://www.jstor.org

\title{
LINKED CITATIONS \\ - Page 1 of 1 -
}

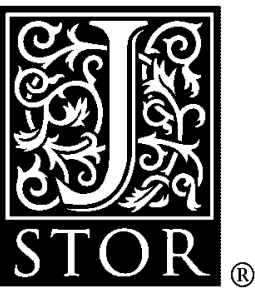

You have printed the following article:

\section{Schumpeter and Quantitative Research in Economics}

\section{J. Tinbergen}

The Review of Economics and Statistics, Vol. 33, No. 2. (May, 1951), pp. 109-111.

Stable URL:

http://links.jstor.org/sici?sici=0034-6535\%28195105\%2933\%3A2\%3C109\%3ASAQRIE\%3E2.0.CO\%3B2-A

This article references the following linked citations. If you are trying to access articles from an off-campus location, you may be required to first logon via your library web site to access JSTOR. Please visit your library's website or contact a librarian to learn about options for remote access to JSTOR.

\section{[Footnotes]}

\author{
${ }^{1}$ The Common Sense of Econometrics \\ Joseph Schumpeter \\ Econometrica, Vol. 1, No. 1. (Jan., 1933), pp. 5-12. \\ Stable URL: \\ http://links.jstor.org/sici?sici=0012-9682\%28193301\%291\%3A1\%3C5\%3ATCSOE\%3E2.0.CO\%3B2-E
}

NOTE: The reference numbering from the original has been maintained in this citation list. 